\title{
Intellectual Property Arbitrage: How Foreign Rules Can Affect Domestic Protections
}

\author{
Pamela Samuelson†
}

\begin{abstract}
Differences in national intellectual property rules may cause economic activity to shiff from one jurisdiction to another so that a higher-protection rule will be undermined by lower-protection rules of other jurisdictions. This Essay illustrates this with four examples: different rules on the enforceability of anti-reverse engineering clauses of software licenses, the protectability of bioengineered research tools, peer-to-peer file sharing, and exceptions to anticircumvention rules. It considers several options nations may have to respond to such intellectual property arbitrage, none of which is likely to be very effective.
\end{abstract}

\section{Differences in NATIONAL Rules ENABLE IP ARBITRAGE}

The Agreement on Trade-Related Aspects of Intellectual Property Rights (TRIPS), concluded in 1994, has narrowed the range of issues on which nations can adopt differing IP rules. All World Trade Organization (WTO) member nations, for example, must now protect computer programs by copyright law.' Yet TRIPS plainly contemplates continued differences in national laws by signaling that nations are free to adopt higher-protection rules than the required minima ${ }^{2}$ (which presumably means they need not do so). Nations are also "free to determine the appropriate method of implementing the provisions of this Agreement within their own legal system and practice." TRIPS restricts national autonomy by forbidding nations from treating foreigners less well than their own nationals, but this implicitly "accept[s] the proposition that states may differ in their substantive laws." Other TRIPS provisions recognize that member states can adopt IP rules "in a manner conducive to social and economic welfare" and "to promote

$\dagger$ Chancellor's Professor of Law and Information Management, Boalt Hall, University of California at Berkeley. This Essay began as a joint work with Suzanne Scotchmer. Thanks to Eddan Katz for prodigious research assistance. Research support for this Essay was supplied by National Science Foundation Grant No. SES 9979852.

I See Agreement on Trade-Related Aspects of Intellectual Property Rights (Apr 15, 1994), Art 10(1), reprinted in The Legal Texts: Results of the Uruguay Round of Multilateral Trade Negotiations Annex 1C at 325 (Cambridge 1994).

2 See id Art 1(1) at 322 ("Members may, but shall not be obliged to, implement in their law more extensive protection than is required by this Agreement, provided that such protection does not contravene the provisions of this Agreement.").

3 Id.

$4 \quad$ See id Art 3 at 323.

5 Graeme B. Dinwoodie, William O. Hennessey, and Shira Perlmutter, International Intellectual Property Law and Policy $\$ 2.06$ at 79 (LexisNexis 2001). 
the public interest in sectors of vital importance to their socioeconomic and technological development." That significant variations in national laws continue to exist a decade after TRIPS should not be surprising given the diversity of countries' social, economic, and legal traditions; stages of development; and cultures.'

Nations have incentives to adopt higher-protection rules when an already innovative domestic sector demonstrates a need for stronger rules to enable firms to recoup $R \& D$ investments, or when nations believe that doing so will spur investments and economic development in that field of innovation. Nations have incentives to adopt lowerprotection rules if they are predominantly users or net importers of products of that kind, if they aspire to incentivize investments in follow-on innovation, or if they believe that a lower-protection rule will induce more investments than a higher-protection rule."

National differences in IP rules may be unproblematic when the differing rules do not undermine domestic protections. If country $A$ protects a certain innovation (say, patents for higher life forms) and country $B$ does not, country $A$ may be willing to accept that country $B$ 's rule is different as long as it can stop at the border any products from $B$ that would infringe its nationals' IP rights. Firms can set up R\&D facilities in country $A$ and hope to recoup R\&D expenses by exploiting the innovation in $A$ 's market. They have at least partial protection in the global market."

One country's decision to provide more extensive protection than TRIPS requires can produce large externalities for the rest of the

6 TRIPS Arts 7-8 at 324 (ciled in note 1).

7 Sec, for example, Pamela Samuelson, Implications of the Agreement on Trade Related Aspects of Intellectual Property Rights for Culural Dimensions of National Copyright Laws, $23 \mathrm{~J}$ Cultural Econ 95 (1999).

8 Higher-protection rules may also be manifestations of public choice problems with IP legislation insofar as innovative industries are well organized, well tunded, and well situated to benefit significantly from higher-protection rules, making it reasonable to invest in legislation to increase protections to higher levels. Because of the distributed costs of higher-protection rules, collective action problems may prevent those who will bear those costs from organizing effectively to block higher-protection legislation.

9 The E.U. was a net importer of software when it adopted the Council Directive 91/250 of 14 May 1991 on the Legal Protection of Computer Programs, 34 Off J Eur Communities (L 122) 42 (May 17, 1991) (EU Software Directive) (establishing uniform protections for software in the E.U.). The E.U. hoped its rules would enable E.U. firms to engage in follow-on innovation by developing software that would interoperate with U.S. software. See Jonathan Band and Masanobu Katoh, Interfaces on Trial: Intellectual Property and Interoperability in the Global Software Industry 229-44 (Westview 1995) (describing the legislative history of the E.U. Software Directive and the goal of the Directive to "demonstrate support for interoperability and competition, which copyright protection... would frustrate").

10 The U.S decision to grant more extensive patent protection for biotechnological innovations than other nations has caused somc German biotech firms to set up R\&D facilities in the United States. See Susan K. Sell. Private Power, Public Law: The Globalization of Intellectual Property Rights 112 n 16 (Cambridge 2003). 
world. Innovators may be able to recoup investments by selling products in the market where the high-protection rule applies, but they cannot expect to have the same advantage in the world market. Protection in one or a small number of nations necessarily creates a voluntary outflow of profit from the country's own users to foreign innovators without a reciprocal inflow from foreign users to domestic innovators. What is remarkable is that some countries nevertheless do this.

But legal rules in foreign jurisdictions can sometimes limit the force of IP rights in the domestic country. That is, sometimes country $B$ 's decision not to protect an innovation, or to protect it less strongly than $A$, has spillover effects for country $A$. Country $B$ 's decision may, moreover, attract domestic and foreign investments. As Part III will show, country $A$ may not always be able to prevent products developed in country $B$ from entering its market. Unless country $A$ can persuade all nations to harmonize on its higher-protection rule, a lowerprotection rule in even one jurisdiction may undermine $A$ 's rule. Innovators may either have protection everywhere (because $A$ persuaded all nations to adopt its rule) or effectively nowhere (because the lower-protection rule undermines $A$ 's rule). This is the IP arbitrage issue on which this Essay principally focuses.

That differences in national IP rules can affect arbitrage is easily illustrated." Australia currently facilitates arbitrage by permitting the importation of certain IP products (for example, CDs of recorded music) from countries where these products can be purchased at a lower price (say, Thailand) than the recording industry wishes to be the prevailing price in Australia; the arbitrageurs' competition reduces the local authorized sellers' rents. The U.S. has put pressure on Australia to ban such parallel imports. ${ }^{12}$ Because no consensus exists about whether national exhaustion of rights ${ }^{13}$ (the rule preferred by U.S. trade officials) or international exhaustion (the Australian-preferred rule) is the "best" rule," the negotiations leading up to TRIPS did not

11 See, for example, Dan L. Burk, Virtual Exit in the Glohal Information Economy, 73 Chi Kent L Rev 943, 945, 969-72 (1998) (discussing competition among nations as to IP rules).

12 See, for example, Office of the United States Trade Representative, 2002 National Trade Estimate Report on Foreign Trade Barriers: Australia 10-11, online at http://www.ustr.gov/reports/ nte/2002/australia.PDF (visited Nov 4, 2003) (discussing the practice of parallel importation in Australia).

13 For an explanation of exhaustion of rights, see World Intellectual Property Association, International Exhaustion and Parallel Importation, online at http://www.wipo.org/sme/en/ ip_business/export/international_exhaustion.htm (visited Nov 4, 2003).

14 Trade and IP perspectives on this issue point in opposite directions. Trade experts would logically favor international exhaustion because this rule permits goods to flow more freely in the global market, while IP experts often favor national or regional exhaustion because these rules help IP owners recoup R\&D expenses. See, for example, Rochelle Cooper Dreyfuss and Andreas F. Lowenfeld, Two Achievements of the Uruguay Round: Putting TRIPS and Dispute 
resolve the international debate on this particular type of IP arbitrage. ${ }^{1.5}$ If national approaches to the exhaustion of rights issue differ, arbitrage will occur.

The IP arbitrage that is the main focus of this Essay resembles classic arbitrage in that it impairs the ability to maintain a higherprotection rule (or higher price) in one location because market participants can take advantage of a lower-protection rule (or lower price) elsewhere."

\section{EFFECTS OF DIFFERING RULES ON DOMESTIC AND FOREIGN MARKETS}

This Part discusses four examples of IP arbitrage. In each, highprotection domestic rules may be undermined by lower-protection foreign rules that can plausibly be justified as a legitimate national policy choice.

\section{A. Software License Terms Prohibiting Reverse Engineering}

Suppose that a country (say, the U.S.) decides to enforce terms of software licenses that prohibit reverse engineering." A nation might do so to enable domestic developers of proprietary software to protect internal program interfaces as trade secrets, or simply to promote freedom of contract values. ${ }^{1 / k}$

Other nations (say, the European Union) may allow software reverse engineering for interoperability purposes and refuse to enforce license restrictions on reverse engineering. ${ }^{19}$ Such a rule may foster competition and follow-on innovation in its domestic software market.

Resolution Together, 37 Va J Intl L 275, 280 n 12 (1997) (nuting the tension at the TRIPS talks between the free-trade goals of the General Agreement on Tariffs and Trade (GATT) and the WTO, and TRIPS's goal of protecting intellectual property rights).

15 See id; TRIPS Art 6 at 324 (cited in note 1) ("[N]othing in this Agreement shall be used to address the issue of exhaustion of intellectual property rights.").

16 See, for example, A. Michael Froomkin, The Internet as a Source of Regulatory Arbitrage, in Brian Kahin and Charles Nessen, eds, Borders in Cyberspace: Information Poticy and the Global Information Infrustructure 129, 142-54 (MIT 1997) (describing examples of regulatory arbitrage such as the E.U.'s practice of limiting transborder data flows to countries with comparable data protection laws).

17 Compare Vault Corp v Quaid Software Ltd, 847 F2d 255, 269-70 (5th Cir 1988) (holding anti-reverse engineering clauses unenforceable), with Bowers v Baystate Technologies, Inc, 320 F3d 1317, 1323 (Fed Cir 2003) (holding anti-reverse engineering clauses enforceable).

18 See Pamela Samuelson and Suzanne Scotchmer, The Law and Economics of Reverse Engineering, 111 Yale L J 1575, 1607-30 (2002) (discussing reasons why firms adopt proprietary interfaces and assessing economic effects of reverse engineering and contractual restrictions on reverse engineering).

19 See EU Software Directive Arts 6(1), 9(1) at 45 (cited in note 9).

20 See, for example, Thomas Vinje, The Legislative History of the EC Software Directive, in 
Foreign developers who obtain U.S. software can reverse engineer it in the E.U. to make compatible products. The resulting software may then be marketed in the U.S. as well as European markets as long as the compatible software does not infringe U.S. copyrights." The lower-protection European rule would create incentives for U.S.based software developers, as well as E.U. developers, to set up reverse engineering facilities in the E.U. for development of compatible products.

Thus, a foreign rule in favor of reverse engineering may foil a domestic strategy in favor of protecting platforms with proprietary interfaces. The domestic rule enforcing anti-reverse engineering license terms may just shift development offshore-disadvantaging certain domestic innovators but perhaps increasing competition and ongoing innovation.

\section{B. Products of Research Tools}

If a bio-engineered research tool is patented in one nation (say, the U.S.), but not in other countries, ${ }^{22}$ the patentee may find it difficult to control commercially valuable uses of the tools not only in the markets in which no patent has issued, but even in the market in which it was patented.

The main utility of bio-engineered research tools is in developing bio-engineered products, such as drugs or enzymes. If a foreign national obtains a U.S.-patented bio-engineered research tool and uses it outside of the U.S. to develop a commercial drug, the foreign firm can sell the drug developed with the research tool not only in foreign markets in which the tool is not patented, but also in the U.S. market. While the U.S. has forbidden importation of products made outside the U.S. with a U.S.-patented process since $1988,{ }^{21}$ it does not forbid importation of products made outside the U.S. with U.S.-patented products.

M. Lehmann and C.F. Tapper, eds, A Handbook of European Software Law 39,61-63 (Clarendon 1993) (discussing the competition policy rationale for the interoperability provisions of the E.U. Software Directive).

21 See, for example, Computer Associates International, Inc v Altai, Inc, 982 F2d 693, 701-15 (2d Cir 1992) (stating that interfaces are not protected by copyright law).

22 A bio-engineered research tool might be unpatentable for a number of reasons. See, for example, Commission on Intellectual Property Rights, Integrating Intellectual Property Rights and Development Policy: Report of the Commission on Intellectual Property Rights 22-24 (2002) (urging developing countries to develop stringent rules as to the patenting of research tools); Rebecca S. Eisenberg and Robert P. Merges, Opinion Letter as to the Patentability of Certain Inventions Associated with the Identification of Partial cDNA Sequences, 23 AIPLA Q J 1 (1996) (discussing various reasons to question the patentability of some research tools).

23. Sec 35 USC \& 271 (g) (2000).

24 See, for example, Bayer AG v Housey Pharmaceusicals Inc, 340 F3d 1367, 1377 (Fed Cir 2003) (holding that $\$ 271(\mathrm{~g})$ applies only to importation of physical goods, not importation of 
Thus, the domestic protection of research tools may only shift their use to other countries. The tool's proprietor may effectively have no protection, as the tool is unlikely to be used where it is protected. The lack of protection in even one nation may be tantamount to a lack of protection everywhere in the world. ${ }^{2 s}$

\section{Country Codes}

Developers of computer games may try to enhance their profits by embedding country or region codes so that their games will play only on platforms embedded with the same code. This allows gamemakers to sell the same product at different prices in different countries.

Some countries (say, the U.S.) may outlaw circumvention of technical measures, such as country codes, on the theory that strict rules against circumvention will protect game developers from "piracy" (that is, widespread infringement). ${ }^{2 t}$ Foreign jurisdictions (say, Finland) might adopt weaker anticircumvention rules-for example, allowing purchasers of digital products to bypass country codes so they can play games on a platform of their choice ${ }^{27}-$ on the ground that country coding (and concomitant price discrimination) is anticompetitive. ${ }^{2 k}$

data); Amgen, Inc v United States International Trade Commission, 902 F2d 1532, 1538-40 (Fed Cir 1990) (refusing to stop importation of an artificial hormone made abroad using U.S.patented cells, because cells are a "product" rather than a "process").

2.5 Another type of IP arbitrage arising out of differing patent rules may occur when some countries embrace, and others deny, research exceptions to patent infringement. Follow-on innovators may decide to establish R\&D facilities in countries with such exceptions. Otherwiseinfringing research may result in the development of noninfringing new products, which may then be imported to compete with the patentee and its licensees. Exempting research and experimental uses of inventions from the scope of the patent right has achieved considerable acceptance in the international community. See, for example, Janice M. Mueller, No " Dilettante Affair": Rethinking the Experimental Use Exception to Putent Infringement for Biomedical Research Tools. 76 Wash L Rev 1,37-40 (2001).

26 See 17 USC $\$ 1201$ (a)(1)(A) (2000) ("No person shall circumvent a technological measure that effectively controls access to a work protected under this title."); Sony Computer Entertainment America Inc v Gamemasters, 87 F Supp 2d 976, 987 (ND Cal 1999) (deeming the bypass of a country code a $\$ 1201$ (a)(1)(A) violation). But see R. Anthony Reese, Will Merging Access Controls and Rights Controls Undermine the Structure of Anticircumvention Law?, 18 Berkeley Tech L J 619 (2003) (criticizing the treatment of country codes as persistent access controls un. der $\$ 1201(\mathrm{a})(1)(\mathrm{A}))$.

27 Finland proposed to allow circumvention of technical measures for private purposes so long as the person had lawful access to the work. See email from Ville Oksanen, Researcher, Helsinki Institute for Information Technology (Nov 18, 2002) (on file with author).

28 See, for example, Michael Owen-Brown, Regulator Challenges DVD Zones, The Advertiser (Australia) 27 (May 24, 2001) (reporting Australian investigation of DVD country coding spurred by market allocation and discriminatory pricing concerns). See also Joint Answer to Written Questions E-1509/00 and E-1510/00 given by Mr. Monti on behalf of the Commission, 44 Off J Eur Communities (C 53) 157-59 (Feb 20, 2001) (addressing E.U. competition concerns about country coding of DVD players). 
A weaker anticircumvention rule in Finland may mean that the price prevailing there will be the lowest price available anywhere, undermining game-makers' price discrimination strategies. Moreover, insofar as global digital networks permit nationals of a lower-protection jurisdiction to disseminate the means to bypass country codes, the game-makers' price discrimination could be undermined worldwide.

The welfare effects of IP arbitrage that undermines price discrimination are unclear. Price discrimination can, of course, enhance consumer welfare by increasing the total number of users; overall use of an IP product may fall if the producers' price discrimination regime collapses." However, price discrimination in IP markets is not always benign," and TRIPS contemplates that nations can prevent abuses of IP rights. ${ }^{32}$ Country coding achieves technologically what national exhaustion of rights rules would otherwise achieve, and if nations under TRIPS are free to adopt international exhaustion rules, they should also have discretion to adopt anticircumvention rules to achieve the same objective.

\section{Peer-to-Peer File-Sharing Technologies}

Peer-to-peer (P2P) file-sharing technologies are widely used to exchange digital music in the MP3 file format. ${ }^{33}$ Downloading digital music without paying for it, as $\mathrm{P} 2 \mathrm{P}$ technology permits, may constitute copyright infringement. ${ }^{34}$ While developers of $\mathrm{P} 2 \mathrm{P}$ software are typi-

29 DeCSS, a computer program designed to bypass the Content Scramble System (CSS) used to enforce DVD region coding, is widely available on the Internet. See. for example, David S. Tourctzky. Gallery of CSS Descramblers, online at http:/www-2.cs.cmu.cdu/-dst/DeCSS/ Gallery/index.htnl (visited Nov 4, 2003) (cataloging more than thirty different versions of the DeCSS code, including graphical and musical versions).

30 See, for example. William T. Fisher III, Property and Contract on the Internet, 73 Chi Kent L Rev 1203, 1238-40 (1998) (explaining the socially beneficial distributive effects of price discrimination).

3 See, for example. Michael J. Meurer, Copyright Law and Price Discrimination, 23 Cardozo L Rev 55.67. 93 (2001) (noting as an example that price discrimination for entertainment products results in a net transfer from poorer consumers to wealthier shareholders).

32 See TRIPS Art 8(2) at 324 (cited in note 1) ("Appropriate measures, provided that they are consistent with the provisions of this Agreement. may be needed to prevent the abuse of intellectual property rights by right holders or the resort to practices which unreasonably restrain trade or adversely affect the international transfer of technology.").

33 See, for example, Benny Evangelista. Net Music Swappers Fear Wrath of Indusiry, San Fran Chron A1 (July 25, 2003) (estimating 60 million peoplc in the U.S. have used P2P software to download digital music).

34 See In re Aimster Copyright Litigation, 334 F3d 643,65.3 (7th Cir 2003) (upholding a preliminary injunction on the ground that a $\mathrm{P} 2 \mathrm{P}$ developer was unable to articulate noninfringing use of its product): $A$ \& $M$ Records, Inc v Napster, Inc, 239 F3d 1004. 1014-19 (9th Cir 2001) (concluding that Napster users had engaged in copyright infringement). 
cally not directly liable, the recording industry has charged $\mathrm{P} 2 \mathrm{P}$ developers with indirect copyright infringement on various theories."

P2P technology creates another IP arbitrage opportunity. Suppose courts in country $A$ (say, the U.S.) decide that makers of such technologies are indirect infringers, ${ }^{3,}$ but courts in country $B$ (say, the Netherlands) decide that they are not because of substantial noninfringing uses of these technologies." Courts in country $A$ cannot enforce a judgment against a foreign maker of P2P technologies in the absence of domestic assets; furthermore, enjoining the foreign P2P developer will fail to stop domestic users from accessing the technology from foreign sites via the Internet."

The principal result of national differences on indirect copyright liability rules may be to shift development of P2P technologies offshore. The development and distribution of P2P technologies will not stop unless they are banned in all countries."

35 See, for example, Napster, 239 F3d at 1019-24 (affirming contributory infringement and vicarious liability findings against a $\mathrm{P} 2 \mathrm{P}$ developer and granting a preliminary injunction).

36 See, for example, id. But see Metro-Goldwyn-Mayer Studios, Inc v Grokster, Lid, 259 F Supp 2d 1029, 1043, 1046 (CD Cal 2003) (granting P2P developers summary judgment on secondary copyright infringement claims against them because of substantial noninfringing uses).

37 See, for example, Brian Grow, Netherlands Court Ruling Offers Haven to File-Sharing Services, Wall St J B7 (Dec 18, 2002) (describing a Dutch appeltate court ruling that developers of file-sharing software were not liable for copyright infringement, even if their users might be). See also Timothy Wu, When Code Isn't Law, 89 Va L Rev 679, 734-37 (2003) (discussing the effect of legal rulings such as Napster on decisions about the architecture of subsequent P2P systems).

38 See, for example, Burk, 73 Chi Kent L Rev at 960 (cited in note 11) ("[B]ecause of the Intcrnet, interdiction of infringing products may become nearly impossible.").

39 This helps to explain why some P2P developers have moved their headquarters to remote locations. See Wu, 89 Va L Rev at 736 (cited in note 37) (noting that KaZaA's parent company is incorporated in Vanuatu, while Grokster's servers are located in Nevis).

40 Highly decentralized software systems may continue to be used even if developers have shut down their operations. See Grokster, 259 F Supp 2d at 1045:

Defendants provide software that communicates across networks that are entirely outside Defendants [sic] control. In the case of Grokster, the network is the propriety [sic] FastTrack network, which is clearly not controlled by Defendant Grokster. In the case of StreamCast, the network is Gnutella, the open-source nature of which apparently places it outside the control of any single entity.

Another example of IP arbitrage involving digital copyrights is the streaming of digital content that is unlawful in one jurisdiction (say, the U.S.) but lawful in another (say, Canada); streaming services could locate servers in Canada, but attract U.S. residents who access the streamed content online, thereby creating an opportunity for arbitrage. One effort to exploit differences in national rules about streaming digital content resulted in the higher-protection rule prevailing over the lower-protection rule. See Gerry Blackwell, iCrave Just a Hint of Things to Come, Toronto Star (Mar 9, 2000) (describing the shuttering of Canadian web rebroadcasting service iCrave in response to lawsuits filed by U.S. copyright owners alleging violations of U.S. copyright law). 


\section{E. Factors Affecting IP Arbitrage}

A foreign rule's undermining of domestic protection via IP arbitrage is not inevitable. A given form of IP arbitrage is less likely if it involves physical goods that must be transported in a traditional manner (for example, by ships, trucks, or airplanes) such that infringements can readily be detected by examining the goods at the border. Information technologies are more susceptible to IP arbitrage owing to their more intangible nature, the relative invisibility of the key innovations they embody, and the ease of transmitting many of them via the Internet. ${ }^{41}$ Derivative innovations that do not bear the imprint of infringement in the product being distributed (say, drugs made with the aid of research tools) are also more susceptible to IP arbitrage.

\section{POSSIBLE RESPONSES TO IP ARBITRAGE AND ATTENDANT DIFFICULTIES}

A nation that objects to a form of IP arbitrage that undermines its domestic policy has several options. First, it can change its domestic law to broaden import controls or expand the extraterritorial reach of domestic law. Second, it can pressure the "rogue" nation to synchronize rules. Third, it can initiate a complaint against the other nation under the Dispute Settlement Understanding (DSU) of the TRIPS Agreement. Fourth, it can propose amendments to the TRIPS Agreement to achieve a finer degree of harmonization of minimum standards. Fifth, it can close off trade or communication to protect its domestic rules. Sixth, it can accept that some IP arbitrage may be inevitable and adjust its expectations about the benefits it will be able to derive from TRIPS. Various difficulties attend each option. None is likely to be a foolproof solution to IP arbitrage.

\section{A. Enhancing Domestic Protections}

An obvious step for a nation to take in response to IP arbitrage is to amend domestic laws to block that arbitrage. As to products made elsewhere from research tools patented domestically, for example, a nation could ban importation of products made with the aid of domestically patented research tools. As to interoperable software, a nation could change its copyright laws to prohibit importation of computer programs developed in violation of a mass-market license outside that nation. Also possible is legislation authorizing an expansion of the extraterritorial reach of domestic law.

One precedent for expanding domestic law to stop IP arbitrage is Section $271(\mathrm{~g})$ of the U.S. patent law, which forbids the importation 
and sale of products made from processes patented in the United States. ${ }^{42}$ This provision's potential to disrupt domestic businesses sparked controversy when initially proposed. Retailers not only "feared [the abuse of] extended process patent protection ... to harass sellers of products legitimately produced by noninfringing processes" abroad, but also faced liability for selling imported products while unaware of the infringing process by which they were made-a liability that might have extended to "unwitting" downstream purchasers." To address these concerns, Congress limited the reach of Section $271(\mathrm{~g})$ by shielding noncommercial uses and retail sales, and exempted products materially changed by subsequent processes and products that are trivial components of other products.

Similar resistance may arise if nations try to ban importation of products of research tools, unlicensed interoperable software, or the like-especially if domestic support for the stronger-protection rule is weak or equivocal. For example, even if some software developers, such as Microsoft, would support amendments to U.S. copyright law favoring enforcement of license restrictions on reverse engineering of software, such amendments would be opposed by other firms, such as Sun Microsystems, that support reverse engineering. ${ }^{46}$ Thus, internal domestic politics may check a nation's efforts to avoid IP arbitrage by expanding the scope of domestic legal protections.

Nations can also extend the extraterritorial reach of domestic IP law. ${ }^{47}$ U.S. courts regularly invoke a presumption that U.S. laws do not apply abroad unless Congress has expressly so provided. That Congress has not yet done so is notable given how much harm U.S. firms claim from foreign infringements. ${ }^{49}$ Even assuming their enforceability

4235 USC $\$ 271(\mathrm{~g})$.

4.3 See Dan L. Burk, Patents in Cyberspace: Territoriality and Infringement on Clobal Computer Networks, 68 Tulane L Rev 1.63 (1993).

44 The shield applics "unless there is no adequate remedy under this title for infringement on account of the importation or other use, offer to sell, or sale of that product." 35 USC $\$ 271(\mathrm{~g})$.

45 Id.

46 See, for example, Band and Katoh, Interfaces on Trial at 31-39,332-34 (cited in note 9) (documenting the conflicting views loward IP regulation of Microsoft and Sun Microsystems).

47 See, for example, Curtis A. Bradley, Territorial Intellectual Property Rights in an Age of Globalism. 37 Va J Intl L 505, 506 (1997) ("Courts in the United States are increasingly being asked to apply the federal patent, copyright, and trademark statutes to conduct that takes place outside of the country's territorial boundaries.").

48 See id at 507. The Federal Circuit, however, has upheld injunctions against foreign activities. See, for example, Spindelfabrik Suessen-Schurr v Schubert \& Salzer Maschinenfabrik Aktiengesellschaft, 903 F2d 1568, 1577-78 (Fed Cir 1990) (enjoining foreign manufacture of infringing machines "for use in the Unitcd States").

49 See, for example, International Intellectual Property Alliance website, online at http://wwwiipa.com (visited Nov 4, 2003) (estimating $\$ 12.3$ billion in losses from copyright infringement in 49 nations in 2002). 
against nonresidents, extending the reach of domestic IP laws extraterritorially may subvert foreign policy."

In sum, domestic and foreign policy considerations are likely to constrain the ability of a nation to avoid IP arbitrage by amending domestic laws to broaden import controls or to extend the reach of its laws beyond its territorial boundaries. Moreover, banning the import of derivatives, such as products of research tools or products of patented processes, may be difficult to enforce, particularly when the products do not bear the imprint of the infringement and there is more than one way to make them."

\section{B. Putting Pressure on the "Rogue" Nation}

Nations affected by an IP arbitrage may also pressure the other nation to change its law. There is, of course, nothing new about unilateral pressure as a strategy for dealing with perceived inadequacies of other nations' IP laws or practices. ${ }^{52}$ Many expected TRIPS to cause such pressure to subside, ${ }^{53}$ and some have even argued that it is inconsistent with TRIPS obligations for member states to engage in unilateral retribution as to matters covered by the TRIPS Agreement. ${ }^{\text {s. }}$

The U.S. has been the most active and aggressive user of unilateral pressure to induce changes in other nations' IP laws. Prior to the adoption of TRIPS, the U.S. implemented procedures for taking action against nations having IP policies it deemed deficient. The U.S. Trade Representative has authority to investigate whether particular nations adequately protect IP rights, and if not, to deny them trade benefits unless their policies change. ${ }^{55}$ It publishes an annual report assigning a level of priority to the perceived inadequacies of other nations' laws, and takes prompt action against priority violators. ${ }^{56}$ The U.S. has used these procedures to put considerable pressure on other nations to change their IP policies both before and after TRIPS.

50 See Bradley, $37 \mathrm{Va} J$ Intl L at $\$ 46$ (cited in note 47) (noting a strong international reaction to congressional decisions to confer extraterritorial reach to U.S. law).

5I See, for cxample, Rebecca S. Eisenberg, Technology Transfer and the Genome Project: Problems with Patenting Research Tools, S Risk 163, 169-70 (1994).

52 See, for example, Kim Newby, The Effectiveness of Special 301 in Creating Long Term Copyright Protection for U.S. Companies Overseas, 21 Syracuse J Intl L \& Comm 29, 39-46 (1995) (describing U.S. tactics to encourage Taiwan, China, and Thailand to curb copyright and patent infringement).

5. See Sell, Privale Power, Public Law at 165 (cited in note 10).

54 See, for example. J.H. Reichman. The TRIPS Agreement Comes of Age: Conflict or Cooperation with the Developing Countries?, 32 Case W Res J Intl L 441, 454 (2000).

55 See, for example, Newby, 21 Syracuse J Intl L \& Comm at 35-39 (cited in note 52).

s6 See Sell, Private Power, Public Law at 92 (cited in note 10).

57 See id at 124-29. Sce also Newby, 21 Syracuse J Intl L \& Comm at 39-50 (cited in note 52) (providing examples). 
Yet unilateral pressure may founder against some trading partners and as to some issues, depending on the clout of the beneficiaries of the foreign low-protection rule. For example, the E.U. has insisted on the U.S. adopting stricter rules about geographical origin designations for wine, while the U.S. has demanded that the E.U. broaden the availability of patents for biotechnology inventions. ${ }^{\text {s. }}$ Neither bilateral negotiations nor TRIPS has fully resolved these differences. If the U.S. objected to IP arbitrage involving interoperable software, the E.U. would almost certainly resist changes to its policy against enforcement of license restrictions on reverse engineering given how deliberately the E.U. developed its Directive on the Legal Protection for Computer Programs to enable competition and innovation in the software industry."

Less powerful nations have sometimes repulsed U.S. attempts to compel the shoring up of lower-protection rules, such as in the context of developing countries' access to essential medicines. The U.S. put considerable pressure on South Africa and Brazil to prevent them from adopting a compulsory licensing scheme for AIDS drugs to which the pharmaceutical industry objected." Counter-pressures, however, arose from alliances among developing countries with similar concerns, non-governmental organizations concerned with health policy, and a global publicity campaign focusing on the effects of restricting access to essential medicines." The U.S. eventually backed off, although access to essential medicines remains a hotly contested issue. ${ }^{\mathrm{k}}$

Unilateral pressure also undermines incentives for voluntary compliance with TRIPS. ${ }^{\text {h3 }}$ If nations experience equally relentless unilateral pressure after TRIPS as before it, they may believe they have been denied a key benefit of the bargain they thought they had struck when agreeing to TRIPS.

\section{Filing a Complaint with the WTO}

Nations aggrieved by a particular form of IP arbitrage may file a complaint alleging that another WTO member state's low-protection

58 See Sell, Private Power, Public Law at 111-12 (cited in note 10).

59 See Vinje, Legislative History of the EC Sofiware Directive at 61-63 (cited in note 20).

60 See Sell, Private Power, Public Law at 146-62 (cited in note 10) (describing efforts by public health groups and consumer activists to construe TRIPS as permitting compulsory licensing of pharmaceutical patents and the U.S. response).

61 See id at $148-50$.

62 Sec id at 155-58.

63 See, for example, Reichman, 32 Case W Res J Intl L at 458-59 (cited in note 54) (discussing developing countries' possible responses to maximalist interpretations of TRIPS).

64 See Peter M. Gerhart, Reflections: Beyond Compliance Theory-TRIPS as a Substantive Issue, 32 Case W Res J Intl L 357, 368-72 (2000) (modeling TRIPS as an international contract for which developing nations lack an independent arbiter of substantive validity). 
rule violates the TRIPS Agreement. ${ }^{6.5}$ ATO member state may file a "violation complaint" if another WTO member state has adopted a measure impairing or nullifying a TRIPS obligation, or a "nonviolation complaint" if "a member state asserts that any objective of the Agreement is being impeded as a result of any measure applied by another member state, whether or not it conflicts with the [TRIPS] Agreement." The complainant's burden is easier to meet in violation cases: breach of a TRIPS obligation is presumed harmful. ${ }^{67}$ To win a non-violation case, by contrast, "the complaining party must demonstrate not only that it suffered a trade injury ... but that it was justified in relying on the nonoccurrence of that measure or event." Furthermore, there is presently a "working understanding" that non-violation complaints should not be filed. ${ }^{69}$

Challenging forms of IP arbitrage, such as those discussed in Part II, as direct violations of TRIPS will, however, be difficult because they do not involve TRIPS minima. These forms of arbitrage also involve new technology issues as to which there may be no established international norm for the dispute panel to apply." Even if the moratorium on non-violation complaints eventually lapses, winning a nonviolation complaint would be difficult because of the need to prove both harm and reliance on the other's forbearance from adopting the low-protection rule. Thus, concerns posed by IP arbitrage may be difficult to resolve through the WTO dispute process.

\section{Proposing More Detailed Harmonization}

Nations affected by IP arbitrage may propose that the TRIPS Agreement be amended to incorporate additional, more detailed

65 See, for example, David Palmeter, National Sovereignty and the World Trade Organization, 2 J World Intel Prop 77, 79-82 (1999) (discussing the dispute settlement process). A flow chart of the WTO dispute settlement process can be found at World Trade Organization, The Panel Process, online at http://www.wto.org/english/thewto_e/whatis_e/tif_e/disp2_e.htm (visited Nov 4, 2003).

66 Dreyfuss and Lowenfeld, 37 Va J Intl L at 283 (cited in note 14).

67 See id.

68 Id at 284.

69 Gerhart, 32 Case W Res J Intl L at 384 (cited in note 64).

70 A WTO panel may deem an IP rule to be a TRIPS minimum standard even if not expressly required by TRIPS if the rule, by consensus, is a well-established international norm of IP law. See, for example, Dreyfuss and Lowenfeld, 37 Va J Intl L at 289-91 (cited in note 14). The WTO Appellate Body has rejected arguments premised on disappointment of competitive expectations as a basis for claiming a violation of TRIPS. See Reichman, 32 Case W Res J Intl L at 448 (cited in note 54 ).

il TRIPS is silent on anticircumvention laws and regulation of technologies with substantial noninfringing uses. Nor does it directly address research tools or software reverse engineering. But see Charles McManis, Taking TRIPS on the Information Superhighway: International In. tellectual Property Protection and Emerging Computer Technology, 41 Vill L Rev 207, 232-52 (1996) (setting forth possible arguments that TRIPS permits reverse engineering of software). 
minimum standards. ${ }^{17}$ Amending TRIPS to increase the level of IP protection required of WTO members, however, will not be easy. ${ }^{73}$ Article 71(2) provides that TRIPS may be amended to adjust member state obligations to higher levels of protection when such norms have been "accepted under [other multilateral] agreements by all Members of the WTO," after which they can be referred "to the Ministerial Conference for action ... on the basis of a consensus proposal from the Council for TRIPS." Negotiations leading up to new multilateral agreements may take many years.

There are several reasons to believe that proposing more detailed TRIPS minima to overcome IP arbitrage would encounter resistance. The lower-protection nation can be expected to oppose any proposal to override its domestic rule. Insofar as that nation could articulate a pro-competition, pro-innovation, or other policy-based rationale for its rule, it may well win support from other nations. Even if the contested measure does not directly impact developing countries, they may ally with the lower-protection nation to fend off more finegrained harmonization. Proposing new harmonized standards would, moreover, open up opportunities for bargaining and concessions that proponents of higher-protection rules might ultimately find very costly."

Finally, the norms in TRIPS will almost inevitably be at a sufficiently high level of abstraction that more than one interpretation will be plausible. No matter how detailed TRIPS minima become, ambiguities and differing interpretations will almost certainly persist, especially given that the emergence of new technologies so frequently poses interpretive challenges for existing norms.

\section{E. Choosing Isolation}

Nations affected by IP arbitrage may also isolate themselves from the global trading community or the Internet so that IP arbitrage can-

72 See Frederick M. Abbott. The Future of the Multilateral Trading System in the Context of TRIPS, 20 Hastings Intl \& Comp L Rev 661,667-69 (1997) (discussing the process of amending TRIPS).

73. See Graeme B. Dinwoodie, The Development and Incorporation of International Norms in the Formation of Copyright Law, 62 Ohio St L J 733, 777-82 (2001) (arguing that national courts should develop substantive bodies of international copyright law to resolve disputes because neither amending TRIPS nor pursuing WTO disputes is likely to achieve international harmonization in light of strong underlying notions of national cultural diversity).

74 TRIPS Art 71(2) at 352 (cited in note 1). See also id Art 71(1) at 352 (permitting the TRIPS Council to consider modifications or amendments to TRIPS in light of new developments).

75 See Gerhart, 32 Case W Res J Intl $\mathrm{L}$ at 360 (cited in note 64) (noting that new rounds of negotiations for higher levels of protection under TRIPS may create new opportunities and incentives for developing countries to exaggerate the costs of compliance and insist on new concessions). 
not occur. ${ }^{7 h}$ Alternatively, nations can adopt much more restrictive border control measures or build an elaborate firewall to impede Internet communications deemed objectionable."

But isolationism entails considerable costs. An underlying premise of TRIPS and other WTO Agreements is that international trade is a net positive for member states, their nationals, and the world economy. Self-imposed embargos, virtual or real, prevent domestic firms from accessing goods and services that may be important to domestic industrial capabilities. ${ }^{\text {Th }}$ They also dampen prospects for foreign investment. Moreover, developing more extensive border controls or building firewalls will be expensive, with cost rising with restrictiveness. ${ }^{74}$ The costs of isolationism are likely to be so substantial as to make this option infeasible for most nations.

\section{F. Accepting IP Arbitrage}

It is, of course, possible for nations confronted with IP arbitrage simply to accept that the arbitrage has occurred and that their rule is infeasible to enforce. In some cases, nations can resort to other mechanisms for enabling domestic innovators to obtain resources necessary to support R\&D in the particular field. For example, public funding for the development of research tools may provide adequate incentives for their development, obviating the need for patents to serve this function."

\section{CONCLUSION}

TRIPS has not eliminated economic incentives for nations to adopt, depending on their domestic circumstances, higher- or lowerprotection rules. Innovators in nations with higher-protection rules will often, but not always, be able to enjoy at least partial protection in that nation's market. A lower-protection foreign rule will sometimes undermine a higher-protection domestic rule by creating incentives to

76 Only North Korea and Myanmar have chosen not to connect to the Internet. See Froomkin, Internet as a Source of Regulatory Arbirrage at 144 (cited in note 16).

77 See id at 144-46 (describing Vietnamese, Singaporean, and Chinese efforts to control Internet access).

78 See id at 146 :

The tighter the filter, the greater the opportunity cost in lost ability to access the rest off [sic] the world's data. . . In order for such a strategy to have any hope of success, [ ] the government must be prepared to resist domestic pressure. pressure from abroad, and especially pressure from foreign firms with local offices that, like those established in Singapore. are likcly to protest loudly at having their data and communications monitored.

79 Sec id.

80 See, for example, Eisenberg, 5 Risk at 165-75 (cited in note 51) (discussing government policy with respect to publicly funded research since 1980 ). 
shift the locus of economic activity to the less protective jurisdiction. Nations affected by IP arbitrage may encounter difficulties when responding either by adjustments to national rules or by actions in the international arena.

Whether IP arbitrage is consistent with TRIPS depends on one's viewpoint. Under a very broad interpretation of TRIPS, ${ }^{\text {,1 }}$ IP arbitrage seems inconsistent with TRIPS because such arbitrage frustrates its objective to enable innovators to recoup $R \& D$ investments on a global basis. ${ }^{82}$ Yet, if one takes the broad view seriously, the most appropriate responses to IP arbitrage would be either to file a WTO complaint or propose amendments to TRIPS. A WTO complaint would be unlikely to succeed as long as the working moratorium on non-violation complaints persists. Unilateral pressure or expansion of the scope of domestic law or its territorial reach may be much more likely to succeed than a WTO complaint or a proposal to amend TRIPS, but these measures would be inconsistent with broadly conceived multilateral obligations.

Under a narrow view, ${ }^{\mathrm{x} 1}$ TRIPS allows broad national discretion to adopt locally appropriate rules to promote domestic development objectives. Because some nations will have incentives to adopt higherprotection rules and others lower-protection rules, IP arbitrage may be the inevitable result of economic forces playing themselves out in the global arena. But if TRIPS obligations are truly minimal, it may be fair game for nations with higher-protection rules to exert pressure on nations with low-protection rules or to extend the scope of domestic protection or territorial reach of domestic laws in an attempt to restore partial protection, given the futility of filing a WTO complaint or proposing more detailed harmonization.

If neither the broad nor narrow view of TRIPS is indisputable, it is perhaps understandable that nations with higher-protection rules would both interpret TRIPS very broadly and continue to pressure nations with less protective rules to change them, and that developing

8I See, for example, Jane C. Ginsburg, International Copyright: From a "Bundle" of Na. tional Copyright Laws to a Supranational Code?, 47 J Copyright Socy 265, 284 (2000) ("Intemational uniformity of substantive norms favors the international dissemination of works of authorship. If the goal is to foster the world-widest possible audiences for authors in the digital age. then one might conclude that national copyright norms are vestiges of the soon-to-be bygone analog world.").

82 Although the WTO Appellate Body has rejected a "competitive expectations" test as a measure of TRIPS violations, see note 70 , that may change if the moratorium on non-violation complaints lapses.

8. See, for example, Reichman, 32 Case W Res J Intl L at 448 (cited in note 54) (concluding that "TRIPS law consists essentially of the negotiated rules and no more" and arguing for a "strict constructionist" interpretation of TRIPS obligations). 
nations would both view TRIPS narrowly and yet also object to attempts to strongarm them into adopting higher-protection rules. ${ }^{\mathrm{k} / \mathrm{O}}$

IP arbitrage may neither be inherently at odds with TRIPS nor inherently compatible with TRIPS, but perhaps sometimes at odds, and sometimes compatible, depending on its economic effects. ${ }^{x /}$ IP arbitrage is a manifestation of competition among higher- and lowerprotection rules in the global economy; a higher-protection rule may sometimes be necessary to create adequate incentives for particular classes of innovation, and sometimes not. If lower-protection rules promoting research uses, interoperability, the public domain, and related values are economically sound, then as long as at least one nation adopts them, beneficiaries may include not only residents of the adopting nation, but those of other nations that can obtain access to products via the Internet or through the normal operation of international trade. ${ }^{* / 6}$ For those concerned that very strong IP rules are impeding innovation, competition, and other societal goals, ${ }^{\mathrm{k}}$ as well as for those who believe that "user rights" should become part of the TRIPS agenda, IP arbitrage may provide some good news.

84 See Dreyfuss and Lowenfeld, 37 Va J Intl L at 281 (cited in note 14) ("[T]he architects of the TRIPS Agreement used words - and a concept of minimum standards - that allowed each state to read into the Agreement what it wished to see.").

8.5 See, for example, Steven P. Croley and John H. Jackson, WTO Dispute Procedures, Standard of Review, and Deference to National Governments, 90 Am J Intl L 193, 208-09 (1996) (arguing that deference to national decisionmaking on IP rules is appropriate, except when "selfserving interpretations of the Agreement that are arguably but not persuasively faithful to the text" would "erode the Agreement through interpretation").

86 IP arbitrage may also serve as some, albeit incomplete, check on the public choice problem with intellectual property rules in high-protection jurisdictions.

87 See. for example, Reichman, 32 Case W Res J Intl L at 450-51 (cited in note 54) (discussing developing countries' concerns about TRIPS's social costs).

88 See, for example, Rochelle Cooper Dreyfuss. TRIPS-Round II: Should Users Strike Back?, 71 U Chi L Rev 21 (2004). 


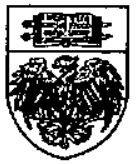

HeinOnline -- 71 U. Chi. L. Rev. 2402004 